Published in "Journal of wine economics", 2020, vol. 15, Special Issue 2, pp. 181-206, which should be cited to refer to this work.

DOI: $10.1017 /$ jwe.2019.30

\title{
Last Frontier Investments: the Case of Alpine
}

\author{
Wines*
}

Philippe Masset, Jean-Philippe Weisskopf, Clémentine Fauchery ${ }^{\dagger}$

December 2018

\begin{abstract}
This article identifies and shows the performance of frontier investments over the period 2002 to 2017 . Using fine wine as a setting we find that the trade frequency and value of frontier investments in the form of Alpine wines has increased over recent years leading to a rise of their prices above inflation rates. We further observe that this frontier investment has been favorable in terms of risk-adjusted returns and volatility for investors. We also evidence that the inclusion of frontier wines in a financial portfolio is beneficial for investors both in terms of returns and diversification benefits due to low correlation coefficients. The identification and investment into frontier investments therefore appears worthwhile for investors looking for new favorable opportunities.
\end{abstract}

JEL Classification: C60, G11, Q11

Keywords: fine wine, wine price, wine investment, Alpine wines

\footnotetext{
*We would like to thank Demian Berchtold, participants at the 2nd Wine and Hospitality Management Workshop and the INFER - INSEEC - LAREFI Workshop on wine macroeconomics and finance for helpful comments.

${ }^{\dagger}$ All authors: Ecole hôtelière de Lausanne, HES-SO // University of Applied Sciences Western Switzerland \& Bordeaux Wine Economics, Route de Cojonnex 18, 1000 Lausanne 25, Switzerland. E-mail: philippe.masset@ehl.ch; jean-philippe.weisskopf@ehl.ch (contact author); clementine.fauchery@ehl.ch
} 


\section{Introduction}

Following the Global Financial Crisis (GFC) central banks such as the Federal Reserve or the European Central Bank have resorted to low interest rates and quantitative easing as a way to spur the economic growth and investments. As a consequence, institutional investors, High Net-Worth Individuals and to a lesser extent retail investors have been on the lookout for new investment ideas beyond traditional equity and fixed income. This search for alternatives has led investors to consider more exotic assets such as commodities, real estate or collectibles. These tangible assets are deemed beneficial from a diversification perspective due to their low correlations with traditional assets and are meant to deliver high returns as they become more financialized through time. The evolution over this potentially porous and vague investment frontier between pure consumer goods (without a true financial dimension) and assets trading on secondary markets should go hand in hand with price increases.

This paper answers the question whether it is interesting for investors to place themselves in the proximity of this frontier and to identify the next good breaking the frontier from consumer good to financial asset. A priori it seems that it is worthwhile for an investor to do so to gain access to high returns and strong diversification benefits. The market for fine wine constitutes an excellent setting to study these questions as a small part of the market (Bordeaux and Burgundy) has already broken the frontier and has financialized over the last two decades. Another part, on the other hand, will most certainly remain a consumer good and a final part is on the verge of breaking the frontier. In this paper, we examine this last category and want to compare it to already financialized fine wines and traditional financial markets to gain a better understanding of the potential of frontier assets for investors. We, therefore, use the market for Alpine wines from Austria, Germany, Switzerland, Northern Italy and the Rhone valley which are all situated in the perimeter of the Alps or along Alpine rivers and lakes to test four propositions. First, we propose that Alpine wines have entered into a financialization process over the last decade 
and are thus being traded more frequently on secondary markets. We then study the impact of this financialization process of Alpine wines by proposing that their prices have increased at a pace exceeding inflation. Finally, we propose that Alpine wines have delivered positive risk-adjusted returns and have offered a significant diversification potential through low correlations with traditional asset classes and other wine regions.

We show that there is a potential for Alpine wines as financial assets when compared to Bordeaux and Burgundy wines which have already broken through the frontier and are nowadays considered as investment-grade by investors. It appears that all ingredients that pushed these two wine regions towards financialisation are also existent for Alpine wines. Our empirical results confirm our four propositions. We find evidence that the trade frequency and value of Alpine wines at auctions has substantially increased since the GFC. This surge in interest has led to a price increase of Alpine wines which has gone beyond inflation rates over the last ten years in Europe. Finally, the performance analysis allows us to confirm their potential as frontier investments as they display high (abnormal) returns, moderate risk and low correlations with other assets yielding high diversification benefits. More specifically, the difficulty resides in the identification of those assets (or in this case wines) which have not yet or just entered the investment-grade perimeter but which could do so in the not too distant future. Our results indicate that Northern Italian wines have shown a strong dynamic (high prices, positive returns and good diversification). For the German-speaking regions (Austria, Germany and Switzerland) the evolution is more unequal and the dynamic is due to a few wines which have shown strong price increases, returns and diversification benefits. Finally, the Rhone valley which started the closest to the frontier has not been able to deliver comparable returns to the other regions. This can be explained by a double-trend on the market. Collectors, speculators and consumers are getting more and more interested in wines from outside France away from rather heavy, less trendy wines. Moreover, the leaders in this region have not been able to innovate and adapt the style of the wines to 
current demand. The different evolution of these regions which are all situated at different stages of the frontier market suggests that it is a complex task to identify future investment-grade wines, but if successful it is worthwhile from an investor's perspective.

The contributions of this paper are relevant to both practitioners and academics. First, we provide a comprehensive analysis of the market for Alpine wines from Austria, Germany, Switzerland, Northern Italy and the Rhone valley. These regions have only received very limited attention in academia and in the media although wine amateurs and professionals have had them on their list for some time. This appears important in times in which Bordeaux wines have displayed a bust and boom cycle since the GFC and Burgundy wines are becoming more and more disconnected from reasonable price levels. Second, we model and evaluate the price dynamics of these wines. Results suggest that they have performed better than their more famous counterparts from Burgundy and Bordeaux. Of particular interest is their moderate volatility and low correlation with other wines and with traditional financial assets. This observation can be directly linked to the developing literature on the segmentation of the global fine wine market and shows the reason an interest in "emerging" wine markets can be worthwhile. Third, our paper relates to a more general debate in finance on frontier investments, their proper identification and their performance in an investor's portfolio. We are able to show that upon the proper identification of frontier markets it is worthwhile for investors to add these assets to their portfolio.

The remainder of the paper is organized as follows. Section 2 starts with a historical review of wine as an investment and then proceeds with the presentation of a set of four propositions that are analyzed in the empirical part. Section 3 presents the data-set. Section 4 is devoted to the research design used to evaluate the four propositions, the presentation of the results and a discussion of their implications. Section 5 concludes. 


\section{Literature review and development of the con- ceptual framework}

\subsection{A brief historical review of wine as an investment}

The use of wine as an investment is not new. Already in the 1970s, wine collectors and amateurs were trying to make a profit on this market. The first empirical studies on the topic were also published in this period. Using a limited data-set consisting of Bordeaux wines, Krasker (1979) depicted a disappointing performance of such investments. Jaeger (1981), however, arrived at a completely opposite conclusion. These conflicting results can be explained by the fact that Krasker's sample covered the period 1973 to 1977, whereas Jaeger's sample went back to 1969. In the early 1970s, Bordeaux prices increased rapidly, but then dropped in the aftermath of the 1973 oil crisis.

The 1980s have been marked by the massive arrival of U.S. consumers on the wine market. Several excellent vintages spurred an increase in demand which led to rising prices. This trend was however stopped by the recession in the early 1990s and a string of four difficult vintages (1991 to 1994). Over this period, few academic papers were published. They devoted most of their attention to the analysis of price determinants (e.g., Di Vittorio and Ginsburgh (1996)), but some studies also examined the returns to an investment in wine (e.g., Burton and Jacobsen (2001)). Both the market and research was dominated by Bordeaux.

Following very good harvests in 1995 and 1996, prices started to rebound. In just four years, between 1994 and 1998, prices of Bordeaux wines almost doubled. The trend continued until 2000 and was only moderately slowed down by the bust of the dot-com bubble and the recession that followed 9/11. The release of the 2005 vintage, deemed "vintage of the century" spurred an impressive price hike. For the first time, young Bordeaux wines were trading at more than $\$ 1,000$ a bottle. This period is marked by the beginning of the globalization and the financialization of the wine market. Notably, Liv-ex, the now leading player on the market, launched 
its activities in 1999 and it soon started providing benchmarking and valuation tools dedicated to wine collectors and investors. Some other regions started to emerge from the shadow of Bordeaux and attracted more interest from buyers and collectors-alike (e.g., Burgundy and California). ${ }^{1}$ In parallel, the literature on the topic also put more emphasis on financial issues related to risk and return of wine investments (Fogarty (2006)) and their risk-adjusted performance (Sanning, Shaffer, and Sharratt (2008)).

The global financial crisis marked a pause in the expansion of the wine market but the trend resumed rapidly after financial markets emerged from their bear market phase. The rapid recovery of the wine market can be attributed to different phenomena. First a string of excellent vintages (2009, 2010, 2015, and 2016) spurred demand. At the same time, both supply and demand turned more global with the arrival of buyers from emerging markets such as China (Masset, Weisskopf, et al. (2016)) and the appearance of new wine growing regions selling wines to a now global consumer base. The wine market also continued its evolution from a pure consumer to a more financialized market with the development of dedicated tools and instruments. Liv-ex and other information providers started or improved existing wine market indices and first wine investment funds emerged (Masset and Weisskopf (2015)). Wine research equally expanded dramatically on a wider and more in-depth array of topics related to the diversification potential of wine (Fogarty (2010); Aytaç and Mandou (2016)), its risk-adjusted returns (Masset and Weisskopf (2010)) or the life-cycle of such investments (Dimson, Rousseau, and Spaenjers (2015)). The results on the potential for wine as an asset class, however, are not unanimous.

The apparent conflicting results found in the literature can be rationalized through two complementary explanations. First, the periods considered by the various researchers are different and the results are thus not directly comparable. The fact

\footnotetext{
${ }^{1}$ For instance, in California, Sine Qua Non started producing their own wines in 1994. They soon became so fashionable that it was almost impossible to find/purchase them. Likewise in Burgundy many wineries that were regarded as "very good" in the mid-nineties are now considered as "cult" and only sell to loyal customers via a complex allocation system.
} 
that the results are sensitive to the sample period used illustrates the cyclical nature of an asset that does not deliver cash-flows to its owners. Second, the various studies use data samples composed of wines from different origins and with diverse levels of reputation and status. The impact of such methodological choices on the outcome of the various studies illustrates the heterogeneity of the wine market. There is not a single but rather several segmented wine markets. Nowadays, great wines can be found in many different regions and at various price levels. But only a handful of these fine wines can be considered as investment-grade. They mostly come from Bordeaux and, to a lesser extent, from Burgundy, California and a few other regions. The others are still mostly regarded as consumer goods. The key distinction between these two types of wines lies in the specific reputation and status that the former have built over time and which is difficult to replicate by the later. Investment-grade wines are thus available in limited quantities, but they are sought-after by an ever increasing number of wealthy people, collectors and investors alike. Their prices should thus increase at a pace which substantially exceeds inflation. Other fine, but non-investment-grade wines, on the other hand, come from different regions and are available in larger quantities. Their demand is rather stable and thus their prices should evolve in line with inflation.

\subsection{Development of the conceptual framework}

In the case of tangible assets the distinction (or frontier) between pure consumer good and an asset trading on secondary markets and appreciating in value is vague. For investors being able to place themselves on this frontier and anticipate which goods will evolve towards a financial asset is certainly worthwhile. Higher returns (by crossing the frontier) and an increased diversification potential (due to the hybrid and moving nature of these assets) are to be expected. Wine offers an ideal field to investigate these questions. We are in the presence of many excellent wines and a booming market which is still concentrated on a small but increasing set of key regions and wines. We structure our analysis around four propositions which 
will be tested in the empirical part of the paper. Alpine wines (Austria, Germany, Switzerland, Northern Italy and the Rhone valley in France) are interesting as only very little is missing for them turning from a qualitative consumer good status to an investment-grade asset status. Masset and Weisskopf (2013) make reference to five dimensions which have to be satisfied for a wine to be traded actively on a secondary market: quality, aging potential, scarcity, reputation, history and trendiness. In the case of Alpine wines the first four dimensions are satisfied. According to wine experts the quality and aging potential of these wines are evident. They are regularly awarded scores of 95 to 100 points by The Wine Advocate and are credited with an aging potential of 20 to 50 years. They are also produced in similar quantities to Burgundian producers and are thus rare especially compared to Bordeaux wines. Finally, even if today Bordeaux remains infinitely better known by the public than Alpine wines it has to be noted that the later also possess a rich history, often comparable to Burgundy (Storchmann (2018); Masset and Weisskopf (forthcoming)). For instance, at the beginning of the 20th century German wines were more expensive than the best-known Bordeaux wines. The only point on which these regions have to progress is trendiness, but this has started to evolve. Until the beginning of the 2000s popular wines were concentrated and modern. Nowadays, the market is passionate about authentic and elegant wines. This is reflected by the stylistic change of several Bordeaux wines which have become finer, less oaky and appearing as such in expert comments. This is supported by the growing popularity of Burgundy wines which are of a more elegant and delicate nature. Thus, the classicism of certain wines which was seen as an inconvenience has turned into an advantage. This leads us to our first proposition.

Proposition \#1: Alpine wines have entered into a financialization process over the last decade and are thus becoming actively traded on secondary markets.

Such a process is bound to lead to a modification of the status of such wines which itself will induce an increase in potential clients now consisting not only of consumers 
but also of collectors and investors. The competitive set, on the other hand, will diminish from a large universe of wines for consumption to a more restraint universe of investment-grade wines. This process should naturally lead to an increase in wine prices through a variation in offer and demand. For buyers seeking wines which are crossing the frontier of financialization becomes a wine picking exercise equivalent to stock picking on equity markets. Being a forerunner should therefore lead to higher returns. Commodity markets have followed an essentially similar evolution with strong price increases in the 2000s followed by a downward trend. However, the price determinants are not identical and wine (as well as other collectibles) do not face the same natural limitations commodities do. Commodity demand essentially depends on basic needs by the majority of the global population while the demand for collectibles depends on more specific needs from a more restraint and wealthy fringe of the population. This leads us to our second proposition:

Proposition \#2: Alpine wines have seen their prices increase at a pace exceeding inflation since they became more financialized.

The hybrid status of these wines and their shift from a pure consumer good to a financial asset makes them less sensitive to economic occurrences. This should be reflected in abnormal returns or stated differently these wines should deliver a positive alpha. This is in line with other alternative assets (Kaplan and Schoar (2005)) or alternative alternatives (Blessing (2011)) which have seen their prices increase with their financialization and the arrival of institutional investors. This leads us to our third proposition:

Proposition \#3: Alpine wines have delivered positive risk-adjusted returns since their financialization process started.

The hybrid status and the partial disconnection from economic cycles suggests that Alpine wines should display a relatively low correlation with both traditional financial assets (equity, fixed income, real estate) and the more financialized wines 
from Bordeaux or Burgundy. This geographic segmentation should consequently represent an additional source of diversification for investors and be reflected in a more favorable risk-return trade-off when adding wines from diverse wine regions to a portfolio invested in traditional financial assets. This leads us to our fourth proposition:

Proposition \#4: Alpine wines have maintained a low correlation with traditional asset classes and other wine regions and thereby offer a significant diversification potential.

\section{Data}

We collect auction hammer prices from Steinfels Weinauktionen in Zurich over the period 2002 to 2017. The use of a Swiss auction house has an important advantage. The Swiss wine market is very diverse and consequently does not suffer from a strong home bias such as in Italy or France. This allows us to obtain wine auction data on different wine regions while limiting ourselves to one auction house and country. Economic data (inflation) and financial data (equity, fixed income, real-estate and the Liv-ex are downloaded from Datastream and the Fama French factors from Kenneth French's website.

We define the selection of Alpine Wines according to the following criteria. The producer must be situated in proximity of the Alps. This translates itself by the presence of Alpine lakes and the influence of Alpine rivers (Adige, Ticino and Po in Italy, Rhone in France and Switzerland, Rhine in Germany and Switzerland and the Danube in Germany and Austria). This leads us to three main distinct regions: Alpine wines from German-speaking (Austria, Germany and Switzerland, AGS henceforth), Italian-speaking (Northern Italy) and French-speaking regions (Rhone valley).

[Insert Table 1 about here] 
Table 1 shows the name of the wine producers in this study for the various regions and provides some descriptive statistics for each of them. Mixed lots and unsold lots are not taken into account in the computations. All statistics are available for two sub-periods: the (pre-) GFC period (01/2002 to 12/2008) and the postGFC period (01/2009 to 12/2017). Generally, Alpine wines are cheaper and less frequently traded than their counterparts from Bordeaux and Burgundy. However, we also observe a significant trend with those wines becoming more often traded and increasing relatively rapidly in price since the GFC. In the Alpine wine regions we also find differences. The lowest prices and highest increase in trading activity can be found in the AGS region. While there were close to no trades before the GFC they now have reached levels which are more in line with Northern Italy and the Rhone valley. Price and trading have also increased in these two regions but less so than for Austria, Germany and Switzerland.

\section{Investments in frontier assets}

We hereafter examine the validity of the four propositions. We first examine the evolution of the trading activity of the Alpine wines as compared to two benchmarks, which are Bordeaux and Burgundy. We then estimate indices for Alpine wines and for the benchmark regions, and assess their respective performance: raw and riskadjusted returns, total and systematic risk. Finally, we use the estimated indices to analyze the diversification potential offered by the various wines.

\subsection{Financialization of Alpine wines}

Figure 1 shows the number and value of transactions for the different regions and their evolution per semester (basis of 100 in the first semester of 2009). We observe that the number of trades for wines from the AGS region have dramatically increased since 2009 while it was very limited before 2009. This can be explained by the increase in quality in these regions and the efforts made by producers to better market 
wines and become more visible to the public. For instance, in Switzerland several regional and national initiatives have been launched (Mémoire des Vins Suisses, Swiss fine Wines, rankings, marketing campaigns) and internationally renowned experts have started to cover its wines and awarded high scores (several 99/100 in a recent TWA article). In Northern Italy it is the Piedmont region which drives demand. This region which has been known by insiders for the past 15-20 years has now taken the path of Burgundy two decades ago. Three factors have contributed to this phenomenon. First, it is a region with an immense wine-making tradition, but it is complex and until recently quite obscure. The arrival of an expert (Antonio Galloni) has contributed to put it on the map of a broader public and to make it less complex to understand for customers. Second, consumers want to explore new regions which has been facilitated by the diffusion of information on the Internet. Third, the classic and elegant wine style produced in Piedmont is in line with current consumption trends. The Rhone valley, on the other hand, displays a negative trend. This can be explained by the passion Robert Parker, and consequently many wine drinkers, have displayed for this region's wines since the beginning of the 1990s. This longer dating interest has led to an essentially similar evolution of transactions and values as can be found for benchmark regions of Bordeaux and Burgundy. In other words the Rhone valley was already further on the frontier than AGS and Northern Italy. Finally, these later more mature wine-growing regions display a lower growth even though the transaction values of Burgundy wines have strongly increased since 2009. This once again can be explained by the trend towards a certain style of wine and the fact that Burgundy is currently closing its lateness in comparison to Bordeaux. Results in Table 1 and Figure 1 validate proposition 1. Alpine wines have been in a financialization process and slowly catch up with the already investment-grade and financialized regions of Bordeaux and Burgundy.

[Insert Figure 1 about here] 


\subsection{Index estimation and analysis}

\subsubsection{Index estimation}

We estimate indices for Alpine wines and for the two benchmark regions of Bordeaux and Burgundy using the Repeat-Sales Regression (RSR) approach (Bailey, Muth, and Nourse (1963)), this method does not require the identification of all relevant price attributes. This is a key advantage as compared to the alternative approach, the Hedonic Regression ${ }^{2}$, especially in a context in which wines from different regions are considered.

Let $p_{j}$ denote the log price of wine $j$. Each sale is indexed as follows: $t$ is the time when the first sale took place and tau corresponds to the time when the next sale took place, thus $\tau>t$. The log-return of wine $j$ between dates $t$ and $\tau$ is calculated as $r_{j, t, \tau}=p_{j, \tau}-p_{j, t}$. Equation (1) formalizes the RSR approach (see Masset and Weisskopf (2018) for more details):

$$
r_{j, t, \tau}=\sum_{(n=1)}^{N} \gamma_{n} D_{j, n}+\epsilon_{j, t, \tau}
$$

where $D_{j, n}$ takes the value 1 if wine $j$ was sold in period $\tau,-1$ if wine $j$ was sold in period $t$ and 0 otherwise, $N$ is the number of periods in the data sample. The RSR index is obtained by taking the exponential of the $\gamma_{n}$ estimates of equation (1).

\subsubsection{Analysis of the evolution of the Alpine wine indices}

Figure 2 graphs the evolution of the three Alpine and two benchmark wine indices since 2002 using a bi-annual sampling frequency to reduce the effect of noise and non-synchronous trading activity. We further rescale all index values to 100 in the second semester of 2007 which marks the beginning of an active secondary market for AGS wines. We observe that wines from Northern Italy and the Rhone valley displayed an essentially flat performance between 2002 and 2007. This stands in contrast to Bordeaux and Burgundy which both see their value increase by around

\footnotetext{
${ }^{2}$ This approach aims at estimating a constant-quality index by controlling for all relevant sources of heterogeneity and thus price differences amongst the various wines.
} 
$50 \%$ over the same period. Over the $2007-2017$ period we find that the AGS region performed best with a $60 \%$ increase in value. This is followed by Northern Italy and Burgundy and to a lesser extent Bordeaux. Finally, the Rhone valley has remained a poor investment and has not created any value over this period either.

\section{[Insert Figure 2 about here]}

Table 2 reports descriptive statistics on the wine indices and their benchmarks over the entire sample period and the 2007-2017 sub-period. The Table is further split into two panels: the upper panel considers the indices labeled in their original currency, the Swiss Franc, with Swiss equities, bonds and real-estate as benchmarks. The lower panel reports indices in Euro with appropriate European benchmarks. Given the important fluctuations the Swiss Franc has experienced with respect to the Euro and the fact that most wines come from Euro-zone countries (the only exception being Swiss wines), it seems necessary to control for the effect of currency fluctuations on the results. We observe that the returns for all wine indices (except the Rhone valley) have exceeded the inflation over both the complete sample period (cumulated inflation of around $5 \%$ and $26 \%$ in Switzerland and the Eurozone respectively) and the shorter $2007-2017$ period (1\% and 13\%). This validates proposition 2 for all regions but the Rhone valley and shows that both the older investment grade regions of Bordeaux and Burgundy and the new frontier regions of Northern Italy and Austria, Germany and Switzerland have passed the frontier form consumer good to financial asset.

[Insert Table 2 about here]

The AGS index shows the highest returns, but is also the most volatile index. This may be explained by the heterogeneity of its components with wines from three different countries with a potentially diverse status ranging from more of a consumer good to a financial asset. Over the complete sample period the best performance comes from Burgundy (1st) and Bordeaux (2nd) but if one focuses on the more recent period Northern Italy and Burgundy are second to the AGS 
region and outperform Bordeaux. These observations are in-line with the argument that emerging wine regions getting access to the universe of investment-grade wines should deliver higher returns. Turning to the Euro-denominated results we find a stronger performance of the wine indices. This is due to the strong appreciation of the Swiss Franc with regard to the Euro over the sample period.

The benchmark indices have mainly performed well. Both bonds and real estate have delivered a very strong performance while equity has performed poorly in Europe due to the GFC, the Euro-zone debt crisis and the ensuing recession in most of Europe. Over the complete sample period we also find that the wine market benchmark (Liv-Ex) evolved close to our own Bordeaux index but much less so during the 2007-2017 period. This can be explained by the composition of the Livex which includes young wines as opposed to our index and the depreciation of the British pound since the GFC and the Brexit vote.

\subsection{Risk-adjusted returns}

\subsubsection{Decomposition of the returns of the wine indices}

In order to estimate risk-adjusted returns to an investment in Alpine wines and to better understand the drivers of the performance of such an investment, we run two regressions. We first use a CAPM regression with the market risk factor (MKT) (Sharpe (1964); Lintner (1965)). This allows us to decompose the returns of Alpine wines into a systematic and a specific component and to determine if these wines have delivered abnormal returns over the sample period. The regression model takes the following form:

$$
R_{i, t}-r f_{t}=\alpha_{i}+\beta_{i} M K T_{t}+\epsilon_{i, t}
$$

where $R_{i, t}, r f_{t}$ and $M K T_{t}$ are the return on index $i$, the risk-free rate and the market risk factor at time $t . \beta_{i}$ captures the quantity of systematic risk of index $i$ and $\alpha_{i}$ provides an estimate of its abnormal return. In order to account for non- 
synchronicity and a possible delayed reaction of the wine indices, we also consider a model containing a lagged realization of MKT,

$$
R_{i, t}-r f_{t}=\alpha_{i}+\beta_{i} M K T_{t}+\beta_{i}^{(L)} M K T_{t-1}+\epsilon_{i, t}
$$

In a second step, we replace the market risk factor by the return of the Liv-ex 100 index, which is regarded as the industry leading benchmark. The purpose of this second regression is to better understand how Alpine wines react to the general wine market. As before, we also consider a model containing a lagged realization of the excess return on the Liv-ex. The specifications are as follows:

$$
\begin{gathered}
R_{i, t}-r f_{t}=\alpha_{i}+\beta_{i}\left(R_{\text {Livex }, t}-r f_{t}\right)+\epsilon_{i, t} \\
R_{i, t}-r f_{t}=\alpha_{i}+\beta_{i}\left(R_{\text {Livex }, t}-r f_{t}\right)+\beta_{i}^{(L)}\left(R_{\text {Livex }, t-1}-r f_{t-1}\right)+\epsilon_{i, t}
\end{gathered}
$$

where $R_{\text {Liv-ex,t }}$ is the return on the Liv-ex 100. The other variables and coefficients are identical to those from equation (2) and (3).

\subsubsection{Analysis of risk and adjusted-returns}

Table 3 reports the results from specifications [(2)-(3)] and [(4)-(5)] using bi-annual data to limit the impact of non-synchronous trading and noise.

$$
\text { [Insert Table } 3 \text { about here] }
$$

Panel A reports results for the Swiss market with the Swiss market index (SMI) as benchmark index. We observe an increasing R2 over the period 2007 to 2017 as compared to the complete period but it generally remains low. This indicates that Alpine wines display a different evolution from other assets and may be interesting from a diversification perspective. This is reinforced by positive but low beta coefficients which show that these wines are somewhat sensitive to financial markets but 
remain nevertheless strongly idiosyncratic. Finally, the alpha coefficient is positive for all indices but mostly so for the AGS region and Northern Italy.

Panel B reports results with the Liv-ex translated in CHF as benchmark for the global wine market. This allows us to compare to which extent the different segments on the wine market evolve in unison. We find that the Bordeaux index evolves very similarly to the benchmark index. This may be explained by the composition of our index which is not only composed of the best wines, but also of less liquid wines from Pomerol and St. Emilion and also covers older vintages. Thus our index is less focused on young, liquid and speculative wines than the benchmark index and should consequently display lower risk estimates. More generally, we show evidence that, apart from Bordeaux, all wine indices are less similar to the overall wine market than to the SMI. This indicates that the overall wine market is still mainly composed of Bordeaux wines and that a strong segmentation continues to exist between wine regions. This is of interest to investors as diversification does not only work in relation to financial markets but also inside the wine market. This implies that returns for Alpine wines should be abnormal which is what we find with significantly positive alpha coefficients especially for Austria, Germany, Switzerland and Northern Italy. The overall weaker performance of the Rhone valley can be explained by its longer standing dynamic in the wake of Bordeaux and Burgundy and its lack of new recent speculative wines. It, moreover, shows the complexity of the wine market for which it is difficult to precisely anticipate the dynamics of different regions. These findings validate proposition 3 that an investment in these frontier markets have led to superior risk-adjusted returns.

\subsection{Diversification potential and portfolio analysis}

\subsubsection{Portfolio construction and diversification potential}

In order to analyze the diversification potential of these wines we resort to two approaches. First, we perform a correlation analysis to understand the interrelation of different wine regions amongst each other and in relation to traditional financial 
markets. This allows us to gauge the segmentation of the wine market and how this translates in a broader investment perspective. Second, we construct different investment portfolios. We first construct a benchmark portfolio which replicates the traditional strategic portfolio allocation of an investor consisting of $40 \%$ equity, $40 \%$ fixed income and 20\% real estate. We then examine the impact of adding $25 \%$ wine to this portfolio ${ }^{3}$ by constructing three different wine-invested portfolios. The first has the same structure than the benchmark portfolio but only invests $75 \%$ in the financial assets and $25 \%$ in Bordeaux wines. The second portfolio invests the $25 \%$ wine equally in Bordeaux and Burgundy. Finally, the last portfolio invests $5 \%$ respectively in Bordeaux, Burgundy and each individual Alpine region. The analysis concentrates on two aspects which are of interest to investors. We first compare the performance of each portfolio in terms of risk and return and then compute the risk budget of each asset class to assess the impact of the various assets on overall portfolio risk.

\subsubsection{Portfolio analysis}

Table 4 reports results of the correlation analysis for the different financial and wine indices over the period 2002 to 2017 (Panel A) and 2007-2017 (Panel B). Over the complete sample period we find evidence of three distinct asset categories. The first with positive correlations of around 0.4 includes the interrelations between equity, real estate and the two financialized wine markets of Bordeaux and Burgundy. This suggests that the diversification potential that once existed for these two regions has not entirely vanished but is less pronounced than it used to be and thus reduces their attractiveness in a portfolio setting. The second category displays negative correlations of around -0.4 for the bond market in relation with equity, Bordeaux and Burgundy. Over this period bonds performed very strongly and constitute the most interesting investment from a diversification perspective. Finally, we have a

\footnotetext{
${ }^{3}$ We acknowledge that this is an unrealistic proportion, but it allows us to better illustrate the impact of wine on a portfolio. In practice High Net Worth Individuals have indicated to invest around $10 \%$ in collectibles and $2 \%$ in fine wine (Barclays (2012))
} 
category with correlations of around 0 for Northern Italy and the Rhone valley. While this result is less pronounced than for bonds both regions nevertheless appear to be of interest for diversification purposes by behaving not only differently from traditional financial assets, but also from more financialized wine regions. This further confirms the segmentation existing on the wine market. The period 2007 to 2017 yields similar results with bonds being negatively correlated with equity, Bordeaux and Burgundy. Also these two regions remain positively correlated with equity and real estate but slightly less than over the entire sample period. This is due to the different evolution of equity and Bordeaux prices with the first dropping during the GFC and the second in 2010-11 only. Finally, the AGS region also displays correlations of around 0 and appear equally interesting for diversification as their Northern Italian and Rhone valley counterparts.

[Insert Table 4 about here]

To further investigate the performance of frontier assets we resort to the construction of portfolios in order to judge the potential of this type of investment in a traditional financial portfolio. We once again perform computations over the entire sample period (2002-2017) and the restricted 2007-2017 period.

Over the complete sample period we observe that adding Bordeaux and Burgundy wines to a financial portfolio led to a $10 \%$ increase in returns, but also to a slightly higher volatility. Only adding Bordeaux was less interesting showing that it has been especially Burgundy wines which have driven performance over this period. Finally, we find evidence that investing in both financialized and frontier wine regions led to an equivalent return, but slightly lower risk as compared to only investing in financial assets. Examining the risk budget of the assets we find evidence that it is especially equity driving risk in the various portfolios. This is also true to a lesser extent for real estate and the financialized wine regions. Frontier wines are less prevalent for portfolio risk while bonds contributed negatively to risk due to their negative correlation with other assets. 
[Insert Table 5 about here]

Results on the restricted period between 2007 and 2017 depict a different outcome. Over this period including Bordeaux wine in a portfolio was a poor choice leading to lower returns and essentially equivalent risk. This is due to the burst of the Lafite Rothschild and per extension Bordeaux wine bubble in 2010 during which Bordeaux wines lost up to $60 \%$ of their value. This could be counterbalanced by investing a proportion of the funds in Burgundy which has strongly gained in consumer and investor favour during this period. Finally, adding frontier wines has led to the best outcome increasing returns and lowering risk as compared to the other three portfolios. The risk budget remains similar compared to the complete period but for frontier wines. In this case the risk budget is negative for the AGS region and decreases by more than $50 \%$ for Northern Italy and the Rhone valley. It thus appears that identifying the new frontier markets at the right time leads to valuable outcomes for investors which validates proposition 4 .

\section{Conclusion}

John F. Kennedy stated that "we stand today on the edge of a new frontier - the frontier of the 1960's - a frontier of unknown opportunities and perils - a frontier of unfulfilled hopes and threats." Humans have always tried to expand frontiers and to go beyond the existing or known. In this article, we investigate another type of frontier: the frontier of investable assets. Following the GFC excess liquidity on the markets due to low interest rates and quantitative easing has driven prices of traditional financial assets and of alternative assets up. As a consequence investors have started to push the frontier of investable assets ever further to invest their funds profitably. We today are in an area which can be classified as the frontier of alternative alternatives investments.

Using the market for fine wine as a setting we propose and test four propositions related to last frontier investments composed of Alpine wines. We contrast 
our results with both traditional financial assets and the already financialized wine regions of Bordeaux and Burgundy. We show that Alpine wines on the frontier between consumer good and financial asset have become increasingly popular since the GFC and have seen their number of trades and values strongly increase. This has led prices of Alpine wines to increase more than inflation rates. We further find evidence that Alpine wines have delivered positive risk-adjusted returns and strong diversification benefits in the context of financial portfolios. Overall, it appears that pursuing frontier investments and taking a position on the edge of investable assets has been worthwhile and profitable for investors over the last decade. 


\section{References}

Aytaç, Beysül and Cyrille Mandou (2016). "Wine: To drink or invest in? A study of wine as an investment asset in French portfolios". In: Research in International Business and Finance 36, pp. 591-614.

Bailey, Martin J, Richard F Muth, and Hugh O Nourse (1963). "A regression method for real estate price index construction". In: Journal of the American Statistical Association 58(304), pp. 933-942.

Barclays (2012). Profit or Pleasure? Report. Barclays.

Blessing, Sona (2011). Alternative Alternatives: Risk, Returns and Investment Strategy. John Wiley \& Sons.

Burton, Benjamin J and Joyce P Jacobsen (2001). "The rate of return on investment in wine". In: Economic Inquiry 39(3), pp. 337-350.

Di Vittorio, Albert and Victor Ginsburgh (1996). "Des enchères comme révélateurs du classement des vins. Les grands crus du Haut-Médoc". In: Journal de la société française de statistique 137(2), pp. 19-49.

Dimson, Elroy, Peter L Rousseau, and Christophe Spaenjers (2015). "The price of wine". In: Journal of Financial Economics 118(2), pp. 431-449.

Fogarty, James (2006). "The return to Australian fine wine". In: European Review of Agricultural Economics 33(4), pp. 542-561.

Fogarty, James (2010). "Wine investment and portfolio diversification gains". In: Journal of Wine Economics 5(1), pp. 119-131.

Jaeger, Elizabeth (1981). "To save or savor: the rate of return to storing wine". In: Journal of Political Economy 89(3), pp. 584-592.

Kaplan, Steven and Antionette Schoar (2005). "Private Equity Performance: Returns, Persistence, and Capital Flows". In: The Journal of Finance 60(4), pp. 17911823.

Krasker, William S (1979). "The rate of return to storing wines". In: Journal of Political Economy 87(6), pp. 1363-1367. 
Lintner, John (1965). "Security prices, risk, and maximal gains from diversification". In: The Journal of Finance 20(4), pp. 587-615.

Masset, Philippe and Jean-Philippe Weisskopf (2010). "Raise your glass: Wine investment and the financial crisis". In: AAWE Working paper 57.

Masset, Philippe and Jean-Philippe Weisskopf (2013). "Wine as an alternative asset class". In: Wine Economics: Quantitative Studies and Empirical Applications. Ed. by M.-C. Pichery and E. Giraud-Héraud. Palgrave Macmillan: Basingstoke. Masset, Philippe and Jean-Philippe Weisskopf (2015). "Wine funds: an alternative turning sour?" In: The Journal of Alternative Investments 17(4), pp. 6-20.

Masset, Philippe and Jean-Philippe Weisskopf (2018). "Wine indices in practice: Nicely labeled but slightly corked". In: Economic Modelling 68, pp. 555-569.

Masset, Philippe and Jean-Philippe Weisskopf (forthcoming). "Producing and consuming local: Switzerland as a local market". In: The Palgrave Handbook of Wine Industry Economics. Ed. by Jean-Marie Cardebat and Adeline Ugaglia. Palgrave Macmillan: Basingstoke.

Masset, Philippe, Jean-Philippe Weisskopf, et al. (2016). "Red obsession: The ascent of fine wine in China". In: Emerging Markets Review 29, pp. 200-225.

Sanning, Lee W, Sherrill Shaffer, and Jo Marie Sharratt (2008). "Bordeaux wine as a financial investment". In: Journal of Wine Economics 3(1), pp. 51-71.

Sharpe, William F (1964). "Capital asset prices: A theory of market equilibrium under conditions of risk". In: The Journal of Finance 19(3), pp. 425-442.

Storchmann, Karl (2018). "Germany, Austria and Switzerland". In: Wine's Evolving Globalization. Ed. by Kym Anderson and Vicente Pinilla. Cambridge University Press: New York. 
Figure 1: Evolution of the trading activity (number of transactions and turnover) over time

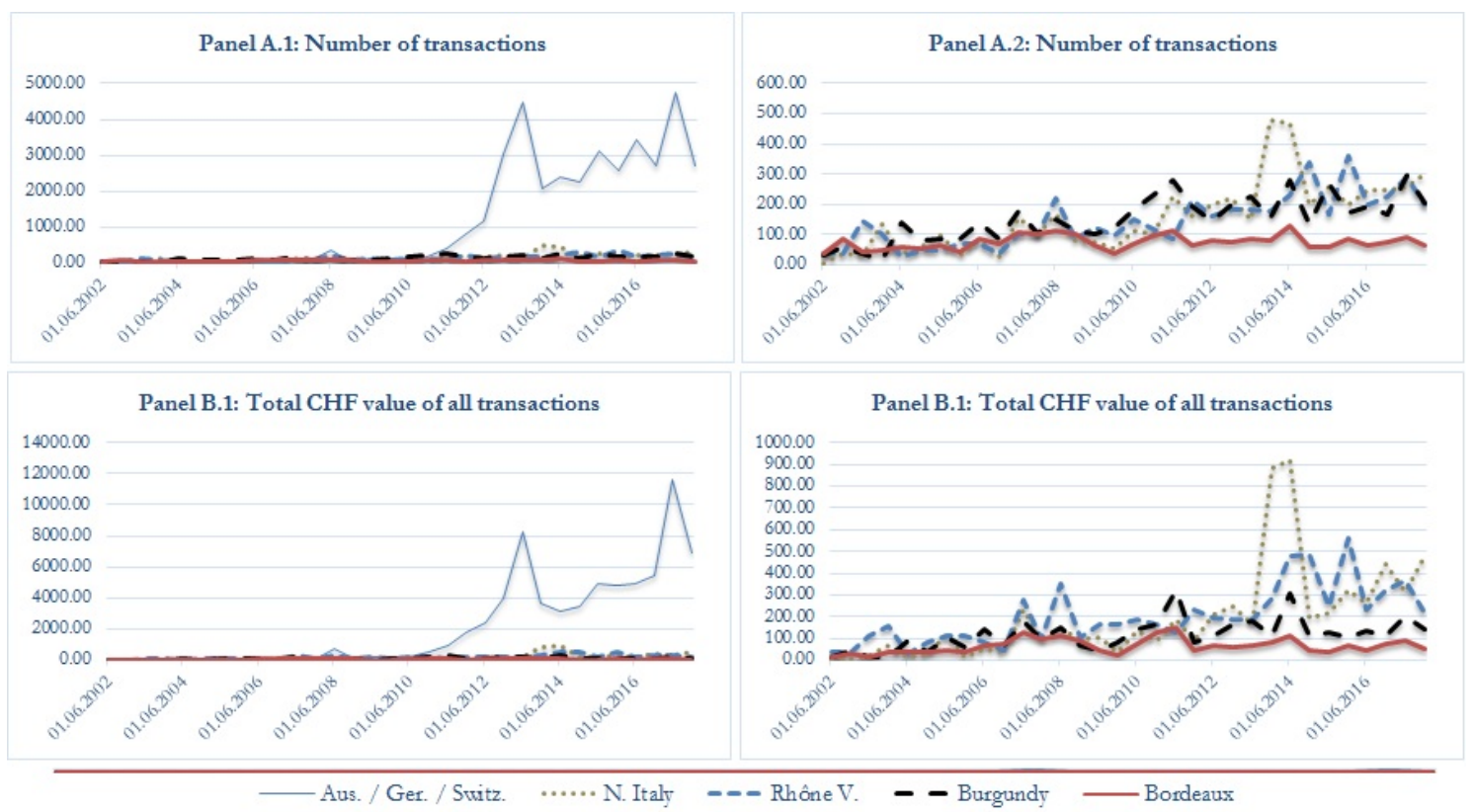

This figure reports the number of transactions and their value. Panels A.1 and B.1 consider all regions and panels A.2 and B.2 do not consider Austria / Germany / Switzerland (As. / Ger. / Switz.). All values have been rescaled with a value of 100 in the second semester of 2007 (which marked the beginning of an active secondary market for the wines from Austria, Germany, and Switzerland). 
Figure 2: Wine indices

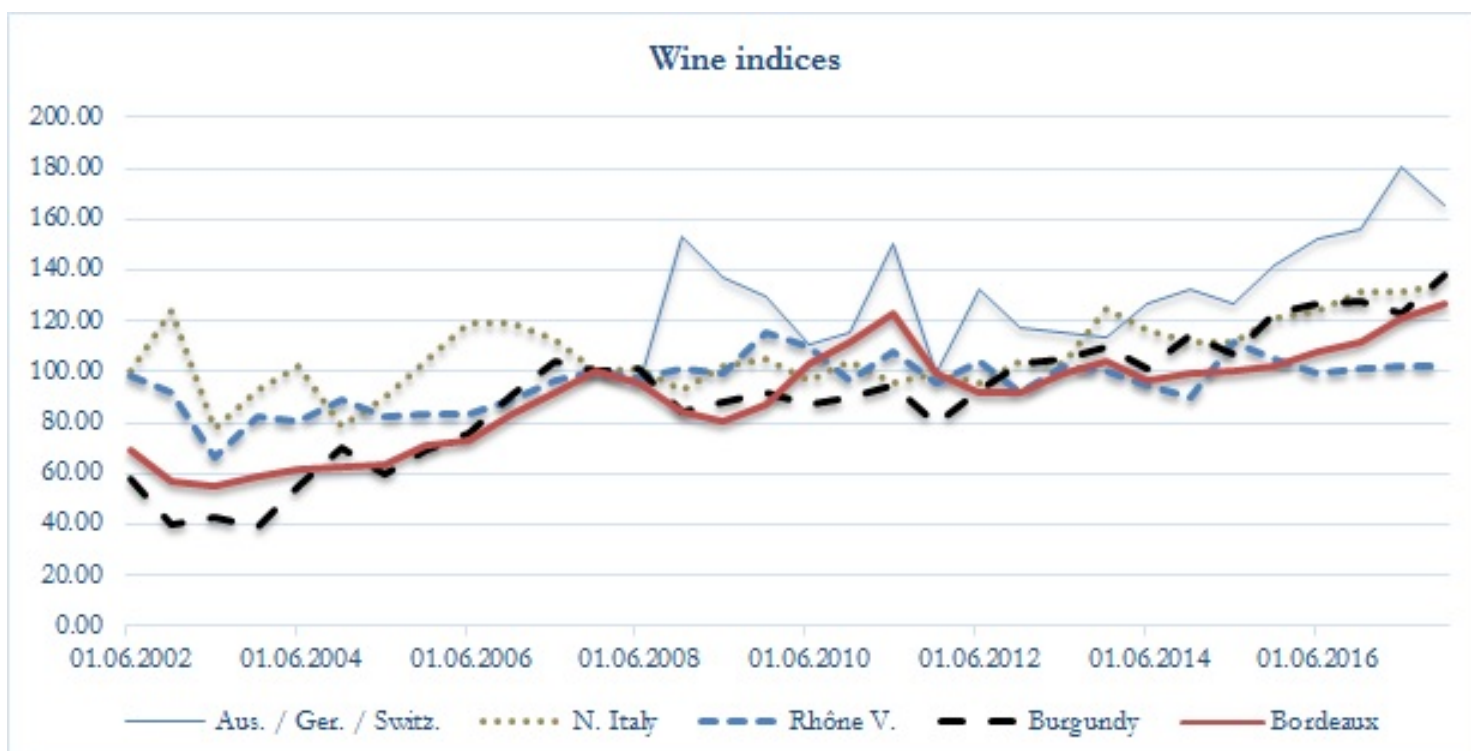

This figure reports the indices computed for five different regions. Aus. / Ger. / Switz. Stand for Austria / Germany / Switzerland. All values have been rescaled with a value of 100 in the second semester of 2007 (which marked the beginning of an active secondary market for the wines from Austria, Germany, and Switzerland). 
Table 1: Average price and number of trades per wine producer per year

This table reports the average price per year as well as the number of trades recorded in a given year. Mixed lots and unsold lots are not taken into account. All statistics are available for two sub-periods: the pre-Global Financial Crisis (GFC) period $(01 / 2002$ to $12 / 2008)$ and the post-GFC period (01/2009 to $12 / 2017)$.

\begin{tabular}{|c|c|c|c|c|c|c|c|c|c|c|c|}
\hline \multirow{2}{*}{ Producer's name } & \multirow{2}{*}{ Region } & \multicolumn{2}{|c|}{ Pre-GFC } & \multicolumn{2}{|c|}{ Post-GFC } & \multirow{2}{*}{ Producer's name } & \multirow{2}{*}{ Region } & \multicolumn{2}{|c|}{ Pre-GFC } & \multicolumn{2}{|c|}{ Post-GFC } \\
\hline & & Nb. Trades & Av. Price & Nb. Trades & Av. Price & & & Nb. Trades & Av. Price & Nb. Trades & Av. Price \\
\hline Dönnhoff & Germany & 0.00 & - & 9.38 & 80.02 & Rostaing & $\begin{array}{l}\text { Rhône } \\
\text { Valley }\end{array}$ & 0.00 & - & 2.88 & 82.40 \\
\hline Robert Weil & Germany & 0.00 & - & 4.88 & 101.84 & Domaine Jamet & $\begin{array}{l}\text { Rhône } \\
\text { Valley }\end{array}$ & 0.00 & - & 2.00 & 121.61 \\
\hline Keller & Germany & 0.00 & - & 5.88 & 157.31 & Clape, A. & $\begin{array}{l}\text { Rhône } \\
\text { Valley }\end{array}$ & 0.00 & - & 2.63 & 71.81 \\
\hline Egon Müller & Germany & 0.00 & - & 5.88 & 164.10 & $\begin{array}{l}\text { Château de Beau- } \\
\text { castel }\end{array}$ & $\begin{array}{l}\text { Rhône } \\
\text { Valley }\end{array}$ & 4.00 & 112.75 & 14.25 & 122.25 \\
\hline J.J. Prüm & Germany & 0.25 & 48.33 & 5.63 & 86.30 & Clos des Papes & $\begin{array}{l}\text { Rhône } \\
\text { Valley }\end{array}$ & 2.00 & 104.08 & 15.00 & 85.11 \\
\hline Diel & Germany & 0.00 & - & 1.88 & 99.46 & Rayas & $\begin{array}{l}\text { Rhône } \\
\text { Valley }\end{array}$ & 5.00 & 260.31 & 7.25 & 265.21 \\
\hline Pöckl & Austria & 0.00 & - & 1.63 & 67.80 & Pégaü & $\begin{array}{l}\text { Rhône } \\
\text { Valley }\end{array}$ & 2.75 & 171.07 & 8.63 & 159.67 \\
\hline Knoll Emmerich & Austria & 0.00 & - & 2.25 & 31.45 & Clos St-Jean & $\begin{array}{l}\text { Rhône } \\
\text { Valley }\end{array}$ & 0.00 & - & 6.88 & 139.94 \\
\hline Hirtzberger & Austria & 0.00 & - & 2.25 & 54.58 & Usseglio P. & $\begin{array}{l}\text { Rhône } \\
\text { Valley }\end{array}$ & 0.88 & 69.60 & 4.75 & 101.16 \\
\hline Schwarz Johann & Austria & 0.00 & - & 1.25 & 50.09 & Bonneau Henri & $\begin{array}{l}\text { Rhône } \\
\text { Valley }\end{array}$ & 0.38 & 276.67 & 2.50 & 264.65 \\
\hline Heinrich Gernot & Austria & 0.00 & - & 1.38 & 53.62 & DRC & Burgundy & 18.63 & 1001.11 & 45.88 & 1645.37 \\
\hline Pichler F.X. & Austria & 0.00 & - & 1.50 & 53.04 & Roumier G. & Burgundy & 17.25 & 660.01 & 24.38 & 460.22 \\
\hline Kracher Alois & Austria & 0.00 & - & 1.38 & 80.07 & Rousseau A. & Burgundy & 12.63 & 287.99 & 34.13 & 469.73 \\
\hline Moric Roland & Austria & 0.00 & - & 1.38 & 55.17 & Comtes Lafon & Burgundy & 13.00 & 482.25 & 26.00 & 291.04 \\
\hline Gantenbein & Switzerland & 0.50 & 58.75 & 20.88 & 115.12 & Leroy & Burgundy & 5.50 & 250.77 & 22.00 & 508.55 \\
\hline $\begin{array}{l}\text { Vinattieri Ticine- } \\
\text { nese }\end{array}$ & Switzerland & 0.50 & 67.08 & 6.38 & 70.52 & Comte de Voguë & Burgundy & 8.00 & 623.06 & 20.38 & 461.66 \\
\hline Gialdi & Switzerland & 0.00 & - & 2.75 & 34.57 & Grivot J. & Burgundy & 7.50 & 131.80 & 13.38 & 145.33 \\
\hline $\begin{array}{ll}\text { Marie } & \text { Thérèse } \\
\text { Chappaz } & \\
\end{array}$ & Switzerland & 0.00 & - & 1.88 & 38.74 & Dugat-Py & Burgundy & 0.88 & 333.81 & 16.75 & 303.83 \\
\hline Cantina Monti & Switzerland & 0.38 & 24.72 & 1.50 & 50.33 & Clair-Daü & Burgundy & 1.50 & 241.80 & 14.50 & 245.50 \\
\hline Guido Brivio & Switzerland & 0.00 & - & 2.50 & 31.28 & Domaine Leflaive & Burgundy & 2.00 & 342.66 & 21.75 & 259.34 \\
\hline Josephus Mayr & $\begin{array}{l}\text { Northern } \\
\text { Italy }\end{array}$ & 0.00 & - & 3.63 & 50.16 & Dujac & Burgundy & 3.25 & 158.55 & 13.63 & 323.91 \\
\hline $\begin{array}{l}\text { Tenuta } \\
\text { Leonardo }\end{array}$ & $\begin{array}{l}\text { Northern } \\
\text { Italy }\end{array}$ & 0.00 & - & 1.13 & 43.30 & Clos de Tart & Burgundy & 2.88 & 195.89 & 9.00 & 244.97 \\
\hline Nino Negri & $\begin{array}{l}\text { Northern } \\
\text { Italy }\end{array}$ & 0.00 & - & 5.88 & 26.73 & Perrot-Minot & Burgundy & 0.50 & 99.32 & 10.00 & 149.58 \\
\hline $\begin{array}{l}\text { Quintarelli } \\
\text { Giuseppe }\end{array}$ & $\begin{array}{l}\text { Northern } \\
\text { Italy }\end{array}$ & 3.00 & 290.07 & 9.38 & 272.03 & Clos des Lambrays & Burgundy & 2.13 & 67.07 & 4.63 & 143.06 \\
\hline Allegrini & $\begin{array}{l}\text { Northern } \\
\text { Italy }\end{array}$ & 1.00 & 49.58 & 8.63 & 41.20 & Ponsot & Burgundy & 1.25 & 193.58 & 5.88 & 177.59 \\
\hline Romano dal Forno & $\begin{array}{l}\text { Northern } \\
\text { Italy }\end{array}$ & 1.13 & 181.94 & 4.75 & 159.01 & Château Margaux & Bordeaux & 89.88 & 318.82 & 122.00 & 316.10 \\
\hline Gaja & $\begin{array}{l}\text { Northern } \\
\text { Italy }\end{array}$ & 13.88 & 129.43 & 34.25 & 138.71 & $\begin{array}{ll}\begin{array}{l}\text { Château } \\
\text { Rothschild }\end{array} & \text { Lafite } \\
\end{array}$ & Bordeaux & 99.13 & 325.28 & 173.38 & 567.19 \\
\hline Giacosa Bruno & $\begin{array}{l}\text { Northern } \\
\text { Italy }\end{array}$ & 1.50 & 163.33 & 17.25 & 246.33 & $\begin{array}{l}\text { Château Mouton- } \\
\text { Rothschild }\end{array}$ & Bordeaux & 343.50 & 304.05 & 482.00 & 371.61 \\
\hline Conterno Aldo & $\begin{array}{l}\text { Northern } \\
\text { Italy }\end{array}$ & 2.13 & 152.94 & 9.75 & 117.64 & Château Latour & Bordeaux & 69.75 & 385.90 & 107.50 & 395.15 \\
\hline Conterno Giacomo & $\begin{array}{l}\text { Northern } \\
\text { Italy }\end{array}$ & 1.88 & 372.39 & 8.75 & 473.16 & $\begin{array}{l}\text { Château Haut- } \\
\text { Brion }\end{array}$ & Bordeaux & 62.13 & 299.78 & 86.25 & 359.48 \\
\hline $\begin{array}{l}\text { Mascarello } \\
\text { Giuseppe }\end{array}$ & $\begin{array}{l}\text { Northern } \\
\text { Italy }\end{array}$ & 1.25 & 106.93 & 7.00 & 150.86 & $\begin{array}{lr}\text { Château } & \text { La } \\
\text { Mission-Haut-Brion }\end{array}$ & Bordeaux & 17.00 & 235.84 & 30.38 & 270.62 \\
\hline Mascarello Bartolo & $\begin{array}{l}\text { Northern } \\
\text { Italy }\end{array}$ & 1.13 & 142.13 & 3.88 & 188.05 & Château d'Yquem & Bordeaux & 30.13 & 650.46 & 54.63 & 414.11 \\
\hline Vietti & $\begin{array}{l}\text { Northern } \\
\text { Italy }\end{array}$ & 0.50 & 99.33 & 4.25 & 122.51 & Château Ausone & Bordeaux & 10.88 & 254.01 & 19.50 & 299.04 \\
\hline Rinaldi Giuseppe & $\begin{array}{l}\text { Northern } \\
\text { Italy }\end{array}$ & 0.00 & - & 3.25 & 157.28 & $\begin{array}{l}\text { Château Cheval } \\
\text { Blanc }\end{array}$ & Bordeaux & 52.63 & 332.90 & 76.25 & 338.54 \\
\hline Voerzio Roberto & $\begin{array}{l}\text { Northern } \\
\text { Italy }\end{array}$ & 0.25 & 94.17 & 3.00 & 122.53 & Château Pavie & Bordeaux & 14.50 & 66.82 & 29.75 & 113.78 \\
\hline Guigal & $\begin{array}{l}\text { Rhône Val- } \\
\text { ley }\end{array}$ & 6.88 & 210.10 & 26.13 & 249.82 & Château Angélus & Bordeaux & 13.88 & 121.87 & 24.38 & 178.52 \\
\hline Chapoutier & $\begin{array}{l}\text { Rhône Val- } \\
\text { ley }\end{array}$ & 6.38 & 95.84 & 22.13 & 124.24 & Pétrus & Bordeaux & 38.88 & 1102.49 & 51.25 & 1462.22 \\
\hline Paul Jaboulet Aîné & $\begin{array}{l}\text { Rhône Val- } \\
\text { ley }\end{array}$ & 8.75 & 104.70 & 16.50 & 153.81 & Lafleur & Bordeaux & 5.13 & 858.58 & 10.63 & 550.63 \\
\hline Chave J.-L. & $\begin{array}{l}\text { Rhône Val- } \\
\text { ley }\end{array}$ & 1.38 & 210.76 & 7.63 & 199.64 & Le Pin & Bordeaux & 2.00 & 852.37 & 2.00 & 1586.88 \\
\hline
\end{tabular}


Table 2: Descriptive statistics on wine indices and benchmarks

Panel A reports descriptive statistics for wine indices expressed in their original currency (CHF), for Swiss equities (Swiss Market Index), bonds (Total return index on Swiss government bond) and real-estate (FTSE EPRA/NAREIT Switzerland) as well as the Liv-ex 100 expressed in CHF. Panel B reports similar statistics but for wine indices expressed in EUR and benchmark indices of the Euro-zone (Euro Stoxx 50, Total return index on Swiss government bond and FTSE EPRA/NAREIT Europe) as well as the Liv-ex 100 expressed in EUR.

\begin{tabular}{|c|c|c|c|c|c|c|c|c|c|}
\hline \multirow{2}{*}{ Panel A:data in CHF } & \multicolumn{5}{|c|}{ Wine indices (in CHF) } & \multicolumn{4}{|c|}{ Benchmarks (in CHF) } \\
\hline & $\begin{array}{ll}\text { Aus. / } \\
\text { Ger. / } \\
\text { Switz. }\end{array}$ & Northern Italy & Rhône Valley & Burgundy & Bordeaux & Equity & Bonds & Real-estate & $\begin{array}{l}\text { Liv-ex } \\
100\end{array}$ \\
\hline \multicolumn{10}{|l|}{ Period 2002 to 2017} \\
\hline \#periods & 21 & 32 & 32 & 32 & 32 & 32 & 32 & 32 & 32 \\
\hline Total return & $65.5 \%$ & $34.2 \%$ & $3.3 \%$ & $139.6 \%$ & $84.8 \%$ & $56.9 \%$ & $86.3 \%$ & $126.0 \%$ & $78.8 \%$ \\
\hline Av. return (per year) & $8.6 \%$ & $3.6 \%$ & $1.3 \%$ & $7.6 \%$ & $4.7 \%$ & $4.0 \%$ & $4.2 \%$ & $5.9 \%$ & $6.1 \%$ \\
\hline Volatility (per year) & $28.8 \%$ & $18.1 \%$ & $15.2 \%$ & $20.0 \%$ & $12.1 \%$ & $14.9 \%$ & $5.8 \%$ & $10.7 \%$ & $21.7 \%$ \\
\hline \multicolumn{10}{|l|}{ Period 2007 to 2017} \\
\hline \#periods & 21 & 21 & 21 & 21 & 21 & 21 & 21 & 21 & 21 \\
\hline Total return & $65.5 \%$ & $34.4 \%$ & $1.9 \%$ & $38.1 \%$ & $27.3 \%$ & $10.6 \%$ & $57.3 \%$ & $54.5 \%$ & $-24.3 \%$ \\
\hline Av. return (per year) & $8.6 \%$ & $3.5 \%$ & $1.0 \%$ & $4.1 \%$ & $3.2 \%$ & $2.0 \%$ & $4.7 \%$ & $4.9 \%$ & $-0.8 \%$ \\
\hline Volatility (per year) & $28.8 \%$ & $10.6 \%$ & $13.5 \%$ & $13.0 \%$ & $12.3 \%$ & $14.0 \%$ & $5.7 \%$ & $10.3 \%$ & $18.6 \%$ \\
\hline \multirow{2}{*}{ Panel B:data in EUR } & \multicolumn{5}{|c|}{ Wine indices (in EUR) } & \multicolumn{4}{|c|}{ Benchmarks (in EUR) } \\
\hline & $\begin{array}{l}\text { Aus. / } \\
\text { Ger. / } \\
\text { Switz. }\end{array}$ & Northern Italy & Rhône Valley & Burgundy & Bordeaux & Equity & Bonds & Real-estate & $\begin{array}{l}\text { Liv-ex } \\
100\end{array}$ \\
\hline \multicolumn{10}{|l|}{ Period 2002 to 2017} \\
\hline \#periods & 21 & 32 & 32 & 32 & 32 & 32 & 32 & 32 & 32 \\
\hline Total return & $134.2 \%$ & $68.6 \%$ & $29.8 \%$ & $200.9 \%$ & $132.2 \%$ & $11.8 \%$ & $178.9 \%$ & $92.7 \%$ & $124.5 \%$ \\
\hline Av. return (per year) & $12.8 \%$ & $5.4 \%$ & $3.3 \%$ & $9.0 \%$ & $6.5 \%$ & $2.4 \%$ & $7.1 \%$ & $6.7 \%$ & $7.5 \%$ \\
\hline Volatility (per year) & $31.8 \%$ & $19.1 \%$ & $18.6 \%$ & $19.2 \%$ & $14.3 \%$ & $18.0 \%$ & $8.8 \%$ & $21.7 \%$ & $21.6 \%$ \\
\hline \multicolumn{10}{|l|}{ Period 2007 to 2017} \\
\hline \#periods & 21 & 21 & 21 & 21 & 21 & 21 & 21 & 21 & 21 \\
\hline Total return & $134.2 \%$ & $90.1 \%$ & $44.1 \%$ & $95.3 \%$ & $80.1 \%$ & $-20.4 \%$ & $101.4 \%$ & $13.0 \%$ & $7.1 \%$ \\
\hline Av. return (per year) & $12.8 \%$ & $7.0 \%$ & $5.1 \%$ & $7.4 \%$ & $7.1 \%$ & $-0.4 \%$ & $7.5 \%$ & $3.6 \%$ & $2.7 \%$ \\
\hline Volatility (per year) & $31.8 \%$ & $10.6 \%$ & $18.4 \%$ & $11.3 \%$ & $15.6 \%$ & $19.5 \%$ & $9.2 \%$ & $21.5 \%$ & $20.0 \%$ \\
\hline
\end{tabular}


Table 3: Results from the single-factor regressions

Panel A reports the results from the single-factor regression when the benchmark is the Swiss Market Index. The standard errors are report below the respective coefficient estimates. The regressions are executed twice, without and with lagged returns on the benchmark. Panel B reports similar results but with a different benchmark the Liv-ex 100 index. The Austrian/German/Swiss index is available only since 2007 and thus no results are reported for the complete period for this index.

\begin{tabular}{|c|c|c|c|c|c|c|c|c|c|c|}
\hline \multirow{5}{*}{$\begin{array}{l}\text { Panel A: } \\
\text { benchmark = } \\
\text { Equities } \\
\text { Period } 2002 \text { to }\end{array}$} & \multirow{2}{*}{$\begin{array}{l}\text { Aus. } \\
\text { Ger. } \\
\text { Switz. } \\
\end{array}$} & \multirow[t]{2}{*}{$\begin{array}{l}1 \\
1\end{array}$} & \multicolumn{2}{|c|}{$\begin{array}{l}\text { Northern } \\
\text { Italy }\end{array}$} & \multicolumn{2}{|l|}{$\begin{array}{l}\text { Rhône } \\
\text { Valley }\end{array}$} & \multicolumn{2}{|c|}{ Burgundy } & \multicolumn{2}{|c|}{ Bordeaux } \\
\hline & & & & & & & & & & \\
\hline & & & $\begin{array}{c}2.5 \% \\
(0.023) \\
\end{array}$ & $\begin{array}{c}1.7 \% \\
(0.023) \\
\end{array}$ & $\begin{array}{c}0.6 \% \\
(0.015) \\
\end{array}$ & $\begin{array}{c}0.7 \% \\
(0.015) \\
\end{array}$ & $\begin{array}{r}4.4 \% \\
(0.032) \\
\end{array}$ & $\begin{array}{r}3.7 \% \\
(0.031) \\
\end{array}$ & $\begin{array}{r}0.8 \% \\
(0.007) \\
\end{array}$ & $\begin{array}{r}0.9 \% \\
(0.007) \\
\end{array}$ \\
\hline & & & $\begin{array}{c}0.03 \\
(0.284)\end{array}$ & $\begin{array}{c}0.32 \\
(0.306)\end{array}$ & $\begin{array}{c}0.34 \\
(0.191)\end{array}$ & $\begin{array}{c}0.31 \\
(0.195)\end{array}$ & $\begin{array}{r}0.68 \\
(0.399)\end{array}$ & $\begin{array}{r}0.65 \\
(0.391)\end{array}$ & $\begin{array}{r}0.30 \\
(0.085)\end{array}$ & $\begin{array}{r}0.30 \\
(0.084)\end{array}$ \\
\hline & & & & $\begin{array}{c}-0.06 \\
(0.279)\end{array}$ & & $\begin{array}{c}0.14 \\
(0.194)\end{array}$ & & $\begin{array}{r}-0.23 \\
(0.391)\end{array}$ & & $\begin{array}{r}0.06 \\
(0.084)\end{array}$ \\
\hline $\mathrm{R} 2$ & & & $0.0 \%$ & $1.8 \%$ & $4.5 \%$ & $4.9 \%$ & $4.0 \%$ & $4.3 \%$ & $14.8 \%$ & $16.9 \%$ \\
\hline \multicolumn{11}{|c|}{ Period 2007 to 2017} \\
\hline & $\begin{array}{c}3.6 \% \\
(0.031) \\
\end{array}$ & $\begin{array}{c}2.8 \% \\
(0.032) \\
\end{array}$ & $\begin{array}{c}2.1 \% \\
(0.024) \\
\end{array}$ & $\begin{array}{c}2.7 \% \\
(0.024) \\
\end{array}$ & $\begin{array}{c}0.9 \% \\
(0.017) \\
\end{array}$ & $\begin{array}{c}0.7 \% \\
(0.017) \\
\end{array}$ & $\begin{array}{r}1.3 \% \\
(0.016)\end{array}$ & $\begin{array}{r}1.5 \% \\
(0.016) \\
\end{array}$ & $\begin{array}{r}0.8 \% \\
(0.009) \\
\end{array}$ & $\begin{array}{c}0.8 \% \\
(0.01) \\
\end{array}$ \\
\hline & $\begin{array}{c}0.09 \\
(0.341)\end{array}$ & $\begin{array}{c}0.22 \\
(0.361)\end{array}$ & $\begin{array}{c}0.10 \\
(0.298)\end{array}$ & $\begin{array}{c}0.08 \\
(0.294)\end{array}$ & $\begin{array}{c}0.33 \\
(0.21)\end{array}$ & $\begin{array}{c}0.34 \\
(0.214)\end{array}$ & $\begin{array}{r}0.46 \\
(0.195)\end{array}$ & $\begin{array}{r}0.46 \\
(0.194)\end{array}$ & $\begin{array}{r}0.29 \\
(0.116)\end{array}$ & $\begin{array}{r}0.29 \\
(0.118)\end{array}$ \\
\hline & & $\begin{array}{c}0.08 \\
(0.348)\end{array}$ & & $\begin{array}{c}-0.39 \\
(0.294)\end{array}$ & & $\begin{array}{c}-0.07 \\
(0.214)\end{array}$ & & $\begin{array}{r}-0.32 \\
(0.194)\end{array}$ & & $\begin{array}{r}0.01 \\
(0.119)\end{array}$ \\
\hline $\mathrm{R} 2$ & $0.2 \%$ & $1.1 \%$ & $0.2 \%$ & $4.4 \%$ & $5.5 \%$ & $6.2 \%$ & $11.8 \%$ & $17.5 \%$ & $13.1 \%$ & $13.0 \%$ \\
\hline $\begin{array}{l}\text { Panel B: } \\
\text { benchmark = } \\
\text { Liv-ex }\end{array}$ & $\begin{array}{l}\text { Aus. } \\
\text { Ger. } \\
\text { Switz. }\end{array}$ & $\begin{array}{l}1 \\
1\end{array}$ & $\begin{array}{l}\text { Northe } \\
\text { Italy }\end{array}$ & & $\begin{array}{l}\text { Rhône } \\
\text { Valley }\end{array}$ & & Burgun & dy & Bordea & \\
\hline \multicolumn{11}{|c|}{ Period 2002 to 2017} \\
\hline & & & $\begin{array}{c}2.3 \% \\
(0.023)\end{array}$ & $\begin{array}{c}2.0 \% \\
(0.023)\end{array}$ & $\begin{array}{c}0.8 \% \\
(0.016)\end{array}$ & $\begin{array}{c}0.9 \% \\
(0.016)\end{array}$ & $\begin{array}{r}5.3 \% \\
(0.032)\end{array}$ & $\begin{array}{r}4.2 \% \\
(0.032)\end{array}$ & $\begin{array}{r}0.6 \% \\
(0.006) \\
\end{array}$ & $\begin{array}{r}0.7 \% \\
(0.006)\end{array}$ \\
\hline & & & $\begin{array}{c}0.26 \\
(0.3)\end{array}$ & $\begin{array}{c}0.38 \\
(0.296)\end{array}$ & $\begin{array}{c}0.08 \\
(0.204)\end{array}$ & $\begin{array}{c}0.08 \\
(0.211)\end{array}$ & $\begin{array}{r}-0.50 \\
(0.426)\end{array}$ & $\begin{array}{r}-0.52 \\
(0.424)\end{array}$ & $\begin{array}{r}0.38 \\
(0.086)\end{array}$ & $\begin{array}{r}0.38 \\
(0.087)\end{array}$ \\
\hline & & & & $\begin{array}{c}-0.41 \\
(0.295)\end{array}$ & & $\begin{array}{c}-0.02 \\
(0.211)\end{array}$ & & $\begin{array}{r}0.37 \\
(0.423)\end{array}$ & & $\begin{array}{r}0.01 \\
(0.087)\end{array}$ \\
\hline $\mathrm{R} 2$ & & & $1.2 \%$ & $4.6 \%$ & $0.2 \%$ & $0.2 \%$ & $2.0 \%$ & $2.8 \%$ & $22.3 \%$ & $22.1 \%$ \\
\hline \multicolumn{11}{|c|}{ Period 2007 to 2017} \\
\hline & $\begin{array}{c}3.6 \% \\
(0.031) \\
\end{array}$ & $\begin{array}{c}3.4 \% \\
(0.031) \\
\end{array}$ & $\begin{array}{c}2.2 \% \\
(0.024) \\
\end{array}$ & $\begin{array}{c}2.4 \% \\
(0.024) \\
\end{array}$ & $\begin{array}{c}1.2 \% \\
(0.017) \\
\end{array}$ & $\begin{array}{c}0.7 \% \\
(0.017) \\
\end{array}$ & $\begin{array}{r}1.4 \% \\
(0.017) \\
\end{array}$ & $\begin{array}{r}1.5 \% \\
(0.017) \\
\end{array}$ & $\begin{array}{r}1.2 \% \\
(0.008) \\
\end{array}$ & $\begin{array}{r}1.1 \% \\
(0.009) \\
\end{array}$ \\
\hline & $\begin{array}{c}-0.09 \\
(0.388)\end{array}$ & $\begin{array}{c}0.05 \\
(0.396)\end{array}$ & $\begin{array}{c}0.08 \\
(0.333) \\
\end{array}$ & $\begin{array}{c}0.03 \\
(0.335) \\
\end{array}$ & $\begin{array}{c}0.30 \\
(0.238)\end{array}$ & $\begin{array}{c}0.35 \\
(0.238) \\
\end{array}$ & $\begin{array}{r}-0.16 \\
(0.231)\end{array}$ & $\begin{array}{r}-0.18 \\
(0.239) \\
\end{array}$ & $\begin{array}{r}0.50 \\
(0.115) \\
\end{array}$ & $\begin{array}{r}0.51 \\
(0.119) \\
\end{array}$ \\
\hline & & $\begin{array}{c}0.48 \\
(0.385)\end{array}$ & & $\begin{array}{c}-0.34 \\
(0.332)\end{array}$ & & $\begin{array}{c}-0.32 \\
(0.236)\end{array}$ & & $\begin{array}{r}0.05 \\
(0.237)\end{array}$ & & $\begin{array}{r}-0.07 \\
(0.118)\end{array}$ \\
\hline $\mathrm{R} 2$ & $0.1 \%$ & $4.0 \%$ & $0.1 \%$ & $2.6 \%$ & $3.6 \%$ & $8.6 \%$ & $1.2 \%$ & $1.4 \%$ & $31.2 \%$ & $31.8 \%$ \\
\hline
\end{tabular}


Table 4: Correlation between wine indices and benchmark assets

This table reports the correlation among the various indices. Panel A reports the results from the complete sample period and Panel B considers only the period during which all indices are available (2007-2017). ***, ${ }^{* *}$ and $*$ indicate significance at the $99 \%, 95 \%$ and $90 \%$-level respectively.

\begin{tabular}{|c|c|c|c|c|c|c|c|c|}
\hline \multirow{2}{*}{ Panel A:Period 2002 to 2017} & \multicolumn{3}{|c|}{ Benchmarks (in CHF) } & \multicolumn{5}{|c|}{ Wine indices (in CHF) } \\
\hline & {$[\mathrm{A}]$} & {$[\mathrm{B}]$} & {$[\mathrm{C}]$} & [1] & {$[2]$} & {$[3]$} & {$[4]$} & {$[5]$} \\
\hline [A] Equity & 1 & $-0.38^{* *}$ & $0.41^{* *}$ & & 0.12 & 0.2 & $0.41^{* *}$ & $0.51^{* * *}$ \\
\hline [B] Bonds & $-0.38^{* *}$ & 1 & -0.18 & & -0.1 & -0.16 & $-0.42^{* *}$ & $-0.49^{* * *}$ \\
\hline [C] Real-estate & $0.41^{* *}$ & -0.18 & 1 & & 0.11 & -0.08 & $0.38^{* *}$ & $0.32^{*}$ \\
\hline [1] Aus./ Ger./ Switz. & & & & & & & & \\
\hline $\begin{array}{l}\text { [2] Northern Italy } \\
\text { [3] Rhône Valley }\end{array}$ & $\begin{array}{c}0.12 \\
0.2\end{array}$ & $\begin{array}{c}-0.1 \\
-0.16\end{array}$ & $\begin{array}{c}0.11 \\
-0.08\end{array}$ & & $\begin{array}{l}1 \\
0.13\end{array}$ & $\begin{array}{c}0.13 \\
1\end{array}$ & $\begin{array}{c}-0.21 \\
0.03\end{array}$ & $\begin{array}{c}-0.04 \\
0.3\end{array}$ \\
\hline [4] Burgundy & $0.41^{* *}$ & $-0.42^{* *}$ & $0.38^{* *}$ & & -0.21 & 0.03 & 1 & $0.42^{* *}$ \\
\hline [5] Bordeaux & $0.51^{* * *}$ & $-0.49^{* * *}$ & $0.32^{*}$ & & -0.04 & 0.3 & $0.42^{* *}$ & 1 \\
\hline $\begin{array}{l}\text { Panel A: } \\
\text { Period } 2002 \text { to } 2017\end{array}$ & {$[\mathrm{~A}]$} & {$[\mathrm{B}]$} & {$[\mathrm{C}]$} & {$[1]$} & {$[2]$} & {$[3]$} & {$[4]$} & {$[5]$} \\
\hline [A] Equity & 1 & $-0.4^{*}$ & 0.27 & -0.31 & 0.31 & 0.14 & $0.42^{*}$ & 0.35 \\
\hline [B] Bonds & $-0.4^{*}$ & 1 & -0.17 & 0.11 & -0.31 & -0.22 & $-0.55^{* *}$ & $-0.53^{* *}$ \\
\hline [C] Real-estate & 0.27 & -0.17 & 1 & -0.19 & 0.01 & -0.24 & $0.45^{* *}$ & $0.4^{*}$ \\
\hline [1] Aus./ Ger./ Switz. & -0.31 & 0.11 & -0.19 & 1 & $-0.44^{*}$ & 0.27 & -0.04 & -0.1 \\
\hline [2] Northern Italy & 0.31 & -0.31 & 0.01 & $-0.44^{*}$ & 1 & -0.29 & 0.27 & -0.03 \\
\hline [3] Rhône Valley & 0.14 & -0.22 & -0.24 & 0.27 & -0.29 & 1 & -0.03 & 0.17 \\
\hline [4] Burgundy & $0.42^{*}$ & $-0.55^{* *}$ & $0.45^{* *}$ & -0.04 & 0.27 & -0.03 & 1 & 0.33 \\
\hline [5] Bordeaux & 0.35 & $-0.53^{* *}$ & $0.4^{*}$ & -0.1 & -0.03 & 0.17 & 0.33 & 1 \\
\hline
\end{tabular}


Table 5: Portfolio and diversification analysis

This table reports statistics on the return and the risk of the four portfolios. The risk budgets of the various asset classes are reported just next to the effective weights (capital invested) which are in italic.

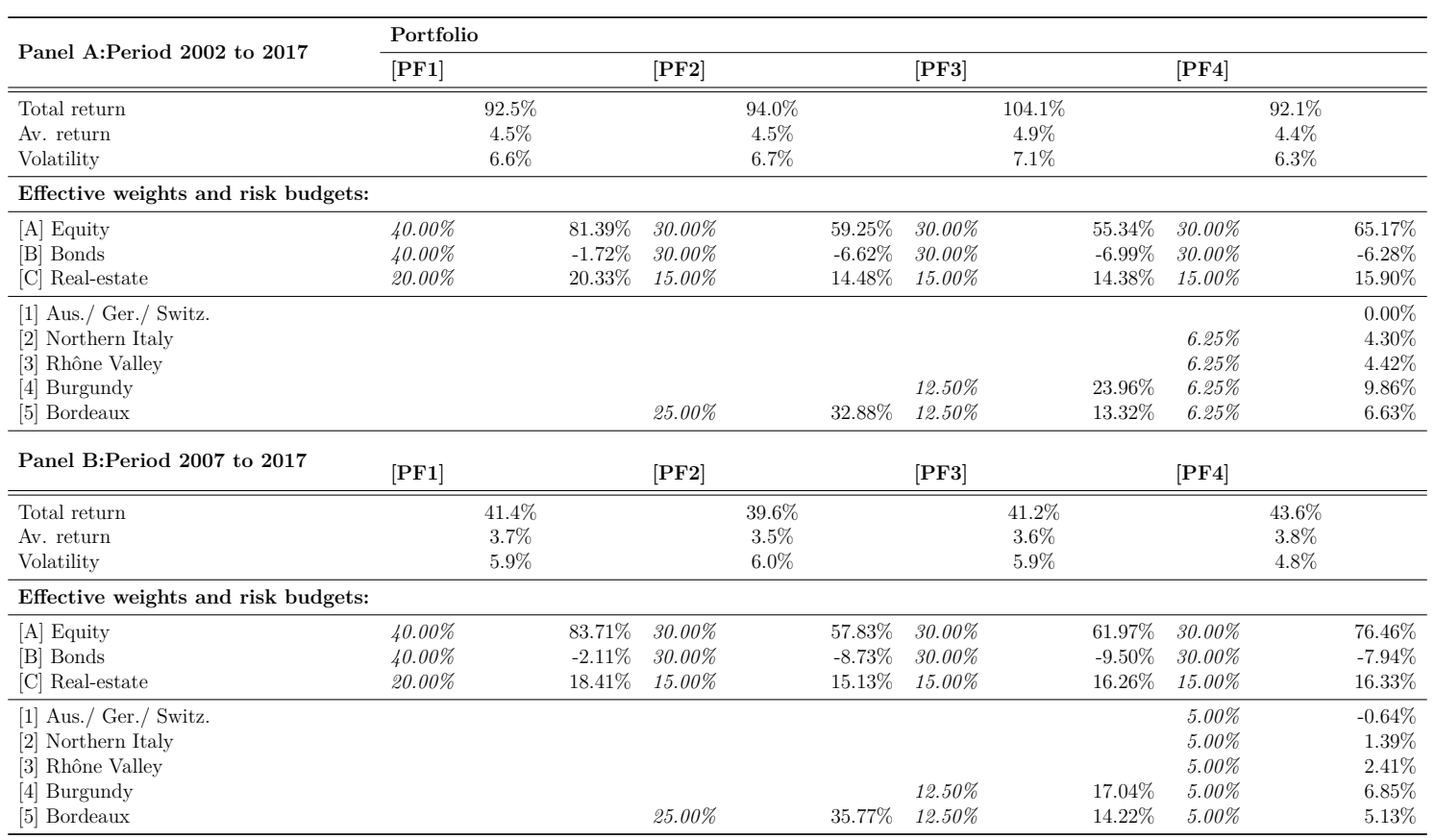

